because of the difficulty of moving their troops, artillery, and supplies through the deep and sticky mud."

Advantage was again taken by the enemy of fog during a dry spell in the second week of April, but the general weather conditions throughout the month were unsettled and not favourable for aggressive work, whilst similarly unfavourable weather prevailed during the greater part of May.

The German offensive was renewed on May 27. A high and steady barometer with light easterly winds prevailed with morning fogs, and similar weather was experienced through the first week of June, whilst in the after part of the month short spells of similar weather occurred

The controlling influence of the weather on the Western front during the summer push commenced by the Allies about the middle of July and continued for so many weeks with such marked success should tell in favour of the Allied meteorologists. The move was undertaken when an exceptionally wet period was drawing to a close, and the lengthy spell of fine and dry weather, with a succession of calms and light winds and a steady, barometer with not too high a temperature, has proved a most favourable weather control. This aggressive move is beyond the period of Prof. Ward's article.

Some interesting occurrences are given in connection with the use of gas; two instances, April ro and Mav I2, are cited of a sudden shift of wind blowing the gas back in the face of the enemy. The Daily Weather Charts, published by the Meteorological Office, support the chance of wind.

The most favourable season for submarine activity is referred to; the smoother water and the longer daylight of summer are mentioned as an advantage in that season, but as an offset in winter there are the longer nights "to come to the surface to re-charge their batteries, to rest their crews, and to make long trips unsubmerged, thereby increasing their effective area.'

A despatch from Rome, dated May 20, mentioned that "the only obstacle which prevents an enemy attack is the weather. . . but the weather is becoming undeniably milder, and the snow is beginning to melt. . . ." The author reminds us that "during the last dars of May the Italians won a brilliant victory in the Tonale region, some $12,000 \mathrm{ft}$. above sea-level, whilst the ground was still covered with snow."

In Palestine a sandstorm on March 16 is referred to as a weather control. under the cover of which "a company of the Turkish Camel Corps was surprised and destroved."

The author states that in the daring raid on the German nayal bases at Zeebrugge and Ostend (April 22) "certain conditions of wind and weather" were waited for, whilst "the losses of the Zeebrugge raiders were due almost entirely to a shift of the wind, which prevented the complete success of the smoke screen."

The prevailing westerly winds occasion much difficulty to our airmen at the front, and an aviator has said: "If an airman ever wishes for a favourable wind, it is when he is breaking for home." Whatever aircraft can do, it is noteworthy that no air raid has as vet occurred in London with an overcast sky.

C. $\mathrm{H}$.

MAGMATIC SULPHIDE DEPOSITS.

PROFS. C. F. TOLMAN AND A. F. ROGERS, of the Leland Stanford University. California, have issued a small volume in the University Series of Publications entitled "A Study of the Magmatic Sulfid Ores." They restrict the term "magmatic ores" somewhat more narrowly than most other writers NO. 2548 , vOL. IOI] on the subject have done, and consider that such ores are not the product of segregation properly so called. The ores studied by them are associated with basic igneous rocks, such as norite, gabbro, peridotite, etc., these rocks occurring generally as small dykes or sills, and comparatively rarely as large laccoliths. The ore is generally segregated at the margins of the intrusives, but occasionally occurs as a lenticular mass well within the magma, and never migrates more than a few feet into the adjoining rocks. Apart from the magnetite-ilmenite group, which is excluded from the present discussion, magmatic ores are divided into two classes, (a) pyrrhotite-chalcopyrite and (b) chalcopyrite-bornite; pyrites is not a typical magmatic mineral. The metallic minerals are formed at a late magmatic stage by a partial replacement of silicate minerals, and there is also evidence of the replacement of one magmatic metallic mineral by another. Hydrothermal alteration is relativelv insignificant, and is distinctly later than the magmatic-ore period. The following is the series of events recognised by the authors as leadino to the formation of magmatio ore deposits :-(a) Crystallisation of primary silicates; (b) development of hornblende and biotite, and occasionally tourmaline and garnet, as magmatic alteration products; $(c)$ introduction of ore-minerals; $(d)$ rearrangement of ores and development of secondary silicates by hydrothermal solutions. The temperature at which the introduction of the metallic minerals commences probably does not exceed $300^{\circ}$ to $400^{\circ} \mathrm{C}$ It will be noticed that the authors ascribe the formation of these magmatic sulphide deposits to causes very different from those generally accepted.

\section{THE PROPOSED UNIVERSITY OF THE EAST MIDLANDS.}

THE movement for establishing a University of the East Midlands took its start some dozen years ago in the growth of the University College, Nottingham, and steps towards obtaining a charter were already being taken before the war. The war seemed at first to stand in the way of further action, but the needs which it brought to light, and the readiness to co-operate which has been displayed through out the East Midland province, have extended the plans of the supporters of the movement. The proposed University will, indeed, have its foundation in the University College, Nottingham, but it is anticipated that the neighbouring cities and counties will enter upon a federal relation through the development of their existing educational institutions and the establishment of new. For example, the Agricultural College which is jointly maintained by the county councils of the East Midlands at Kingston, near Loughborough, is marked out for the agricultural faculty. Further, the close proximity of Leicester, Derby, and Nottingham will make it easv for the services of professors and lecturers in the University to be shared by these three centres.

The Corporation of the City of Nottingham, which founded the University College in $188 \mathrm{r}$, has declared its readiness to hand over the present site and buildings, representing a value of some $200,000 l$, and to make a permanent annual grant of $15,000 l$. when the University charter is granted. The Nottinghamshire County Council has, under similar conditions, promised an annual grant of $5000 l$. The neighbouring authorities are taking up a friendly attitude to the scheme, and have under consideration the form and amount of the assistance to be given. The Mayor of Nottingham has undertaken to raise an endowment fund of $150,000 l$.

The new University, it is expected, will not only 